


\section{UNIVERSITY OF WASHITVTON \\ DEPARTMENT OF OCEANOGRAPHY \\ Seattle, Washington 98105}

Technical Reports

Nos. 162, 163, 164 ,

165,166 , and 167

A COMPIIATION OF ARTICLES REPORTING RESEARCH SPONSORED

BY THE OFFICE OF NAVAL RESEARCH

Office of Naval Research

Contracts Nonr-477(10)

and Nonr-477(37)

Project NR 083012

Reference M66-76

December 1966

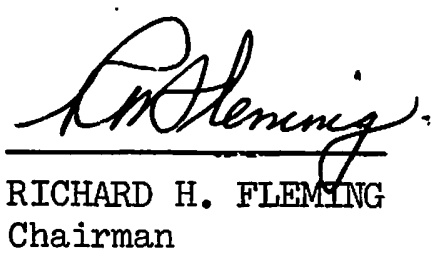

Reproduction in whole or in part is permitted for any purpose of the United States Government 
ARTICLES REPORTING RESEARCH SPONSORED BY THE OFFICE OF NAVAL RESEARCH

Technical Report No. 162

QUASIGEOSTROPHIC FREE OSCIIIATIONS IN ENCLOSED BASINS, by Maurice Rattray, $\mathrm{Jr}$. and Robert I. Charnell. Journal of Marine Research, 24(1):82-103. 1966.

Technical Report No. 163

PALAGONITE TUFFS (HYALOCLASTITES) AND THE PRODUCTS OF POST-ERUPTIVE PROCESSES, by Y. Rammohanroy Nayudu. Bulletin Volcanologique, 27:391-410 +5 plates. 1964.

Technical Report No. 164

CARBONATE DEPOSITS ON PLANTAGENET BANK NEAR BERMUDA, by M. Grant Gross . Geological Society of America Bulletin, 76:1283-1290. 1965.

Technical Report No. 165

DIGGING CHARACTERISTICS AND SAMPLING EFFICIENCY OF THE $0.1 \mathrm{~m}^{2}$ VAN VEEN GRAB, by UIf Lie and Mario M. Pamatmat. Limnology and Oceanography, IO(3):379-384. 1965.

Technical Report No. 166

GRAVITATIONAL CIRCULATION IN STRAIIS AND ESTUARIES, by Donald V. Hansen and Maurice Rattray, Jr. Journal of Marine Research, 23(2):104-122. 1965.

Technical Report No. 167

OXYGEN AND CARBON ISOTOPIC COMPOSITION OF LTMESTONES AND DOLOMTTES, BIKTNI AND ENTWETOK ATOLIS, by M. Grant Gross and Joshua I. Tracy, Jr. Science, ijl(3714): 1082-1084. 1966. 


\section{Extrait du BuLbetin volcanologique Organe de rassogiation DE VOLCANOLOGTE de lidinion geodésique et geophygique intennationale \\ Tome XXVu - 1964}

\section{Palagonife tuffis (hyaloollastités) and the products of post-eruptive proeesses.}

Y. RAMMOHANROY NAYUDÜ

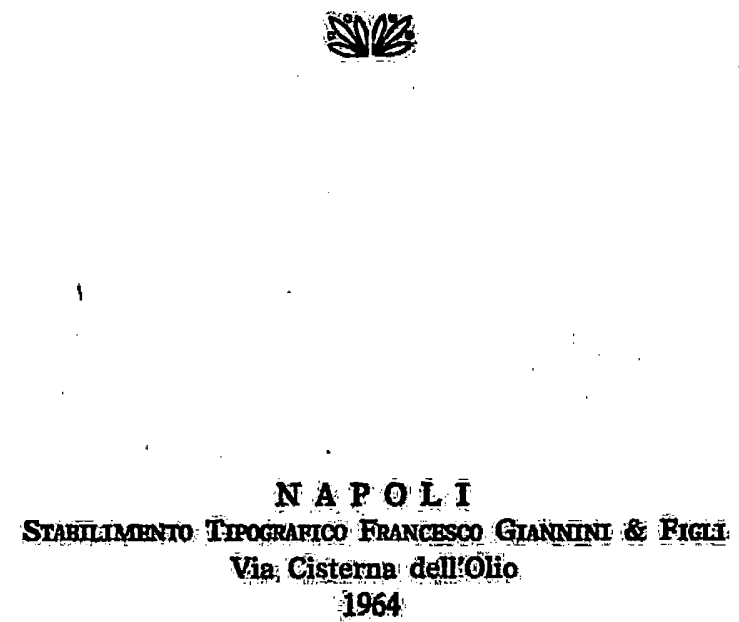
1964 


\title{
Palagonite tuffs (hyaloclastites) and the products of post-eruptive processes. *
}

\author{
Y. RAMMOHANROY NAYUDU ' \\ Scripps Institution of Oceanography, University of California, San Diego, La Jolla, Calif.
}

\begin{abstract}
A synoptic review of the studies of well-known occurrences of palagonite tuffs is presented. Included are palagonite tuffs from Iceland, and pillow-lava palagonite complexes from Columbia River basalts and from the central Oregon coast. Additional petrologic and x-ray defraction data for selected samples are presented. Petrologic evidence shows that basaltic glass of aqueous tuffs and breccias consists of sideromelane, which is susceptible to palagonitization. It is shown that palagonitization is a selective alteration process, involving hydration, oxidation and zeolitization.

Some of the manganese nodules dredged from the Pacific Ocean floor contain nucleus of palagonite-tuff breccias or of zeolite. A brief megascopic and microscopic description of nodules from the south Pacific, the Mendocino ridge and the "Horizon" Nodule from the north Pacific is presented.

Petrographic studies of palagonite-tuff breccias of manganese nodules and other palagonites suggest that migration and segregation of metallic elements occur during and subsequent to palagonitization. During the palagonitization of sideromelane, nearly 30 per cent of sea water is absorbed. The hydration of sideromelane is also accompanied by oxidation of iron and other elements. These oxides may be released either in colloidal form or in true solution and tend to precipitate first from the unstable palagonite.

Available data on manganese deposits associated with submarine volcanism and the petrologic studies presented here show that a genetic relationship exists between palagonite tuffs and ferromanganese minerals of the nodules. It is suggested that palagonitization is an important step in the dissolution and precipitation of the manganese minerals and the associated minerals contained in the nodules.

It is also suggested that some of the red clays associated with manganese minerals are alteration products of palagonite tuffs.

The present study indicates that zeolites and montmorillonite are important post-eruptive products of palagonite. It appears that phillipsite is the dominant zeolite and is genetically associated with palagonite in north Pacific sediments.

* Paper delivered at the IAV scientific session of Aug. 30, 1963 (XIII General Assembly, I.U.G.G.). Part of the cost of printing this paper was borne by a grant-in-aid from the Scripps Institution of Oceanography, University of California, La Jolla.

${ }^{2}$ Present address: Department of Oceanography, University of Washington, Seattle, Washington. Contribution No. 341 of the Department of Oceanography, University of Washington.
\end{abstract}


The mechanism of solution, migration and re-deposition of ferromanganese minerals is not clearly understood. However, the association of zeolites, carbonates and manganese minerals seems to be controlled by a delicate balance between $p H$ and $E h$ variations. Mineralogic associations suggest that these minerals are deposited under high alkaline conditions, which seems to be consistent with observations made by earlier workers.

Pertinent results from the studies of palagonitized basalt from the experimental Mohole drilling are also discussed.

\section{Introduction}

In modern theories of petrogenesis, the mechanism and products of submarine eruptions of basalts have been subjected to much speculation. In dealing with problems where little is known to be certainty, the statement of the eighteenth century French savant Buffon seems most appropriate: «Collect facts and from them ideas will spring 》. The writer has been collecting facts and making observations on the problem of aqueous chilling of basalts and related phenomena.

Available studies on aqueous chilling of effusive basalts of different geologic ages and samples obtained from the Pacific Ocean floor enable one to surmise some of the processes and products involved in submarine basalt eruptions. Glimpses into this phase of submarine geology have been presented by the writer as a working hypothesis for the origin of seamounts (NAYUDU $1962 \mathrm{a}, 1962 \mathrm{~b}$ ). The salient features of this hypothesis are as follows: in the initial stage, basaltic magma erupting on the sea-floor granulates like a molten slag and forms a mound of palagonite tuffs, breccias and pillows. This complex forms a carapace which protects later eruptions beneath it from further aqueous chilling, and allows the flows (sills) below it to crystallize in a normal fashion thus developing a large pile of solid basalt.

In this report a review of the origin of palagonite tuffs is presented. Additional data from the Pacific Ocean are included. The petrography and $x$-ray studies of selected samples and pertinent results from the experimental Mohole drilling are also presented.

The mode of origin of palagonite by hydration of sideromelane (basaltic glass) has been fully described by PEACOcK and FULLER (1928). Their terminology is used throughout this paper.

Main emphasis is focused on the products of post-eruptive processes in palagonite tuffs (hyaloclastites). From the inference drawn it is concluded that some important minerals on the deep-sea floor, mainly manganese minerals, carbonates and zeolites show their genetic relationship to palagonite tuff breccias of submarine origin. 


\section{Historical review of palagonites}

The earliest important work is that of SARTORIUS von WALTERSHAUSEN, who in 1837 noticed a new substance in the matrix of a tuff from Acicastello, Sicily. Later he visited Iceland with Bunsen in 1846. During this visit, Waltershausen observed in the tuffs of the Breccia Formation which is now commonly known as "Palagonite formation " or Moberg formation the widespread and pure development of the same substance that he had previously observed in Sicily. WALTERSHAUSEN (1847) also found the same substance to be widely distributed in the shell bearing tuffs of Palagonia in Val di Nota in Sicily and gave it the name of palagonite. According to him, palagonite is: « a fully transparent wine-yellow to resin-brown mineral of vitreous lustre and hackly concoidal substance being very similar to that of gum arabic or brown sugar. Its hardness scarcely exceeds that of calcite, and its specific gravity is close to $2.64 \%$.

BUNSEN (1851) made chemical analyses of some of the samples collected during his visit to Iceland and showed that palagonite, except for the large and variable water content, agreed in composition with the "normal basalt magma " or to quote directly "Normalpyroxenische Mischung ». However, all the above observations were made from megascopic and chemical analyses and do not include reference to microscopic study. Later microscopic studies revealed that even the purest palagonitefels did not consist of a single homogeneous substance which might be described as palagonite. The following statement by ROSENBUSCH $(1908$, p. 1317) expresses the general conclusions of several investigations that followed Bunsen's work: "It appears that the palagonite substance is not homogeneous, and that analyses of palagonite are bulk analyses of basalt glass together with its alteration products and separated minerals ».

\section{Palagonites of Iceland}

Extensive studies have since been made of the "Palagonite formation " in Iceland. PEAcock in a series of papers (1926 a, $1926 \mathrm{~b}$, $1926 \mathrm{c}$ ) demonstrated that this formation consists mainly of palagonite-tuff and breccia which was formed by the palagonitization of sideromelane, a variety of basaltic glass.

PEACOCK $(1926 \mathrm{~b}, 1926 \mathrm{c})$ stated that palagonite is unstable and tends to crystallize with a partial loss of water into chlorite and zeolites which are two important alteration products. Among the zeolites 
faujasite, analcite, ptilolite and stilbite were recorded. He also found that several sections of palagonite-tuff contained calcite. Peacock stressed the importance of pressure which promotes hydration and inferred that relief of pressure will encourage crystallization of less hydrous minerals. He concluded that the development of chlorite and zeolites is an indication of the relaxation of conditions which promoted palagonitization.

PEACOCK (1926 c, p. 70) demonstrated that the refractive index and water content of palagonite are related roughly in an inverse linear manner. The water content in the most hydrated Icelandic example is about 28 percent.

NOE-NYGAARD (1940) made a comprehensive study of Icelandic volcanics. He presented additional petrologic and chemical evidences on the problem of palagonitization and reported the development of zeolite mass in sideromelane and palagonite. According to him, palagonite breccia consists of basaltic glass of varying sizes cemented together by a zeolitic matrix which is the alteration product of palagonite. In some instances the matrix consists dominantly of calcite. Several observations were made of sideromelane with rims of gel and fibro-palagonite. Birefringent, fibrous zeolites and isotropic zeolites, presumably analcite, developed within these rims.

Most students of the "Palagonite formation " including KJARTaNsson (1943) subscribe to the idea that the basaltic magma was extruded in the water filled chambers under glaciers, resulting in the "Palagonite formation ». In Iceland, the term palagonite has been extended to all kinds of deposits which include fragmented subglacial basaltic lavas, glacial moraines, tuffs and alluvial deposits.

Concerning the term palagonite, RITTMANN (1961) states: "This term is confusing, since these are in no sense pyroclastic tuffs, but deposits formed from the comminuted glassy shells of growing pillows, for which no entirely satisfactory name has yet been found ". To avoid ambiguity associated with the term, he proposed a new term « hyaloclastites » for primary palagonites.

\section{Palagonites from the Columbia River Basalt}

Widespread pillow-lava palagonite complexes are found in the Columbia River basalt where the flows entered lakes formed by lavas disrupting former drainage. PEACOCK and FULLER (1928) considered that palagonitization of the Columbia River basalt is essentially a primary 
or syngenetic phenomenon brought about by the aqueous chilling and granulation of basaltic magma and the subsequent alteration and hydration of the hot sideromelane glass brecciated to palagonite.

FULLER, in a classical series of papers (1931, 1932, 1934, 1950) showed that the yellowish tuffaceous rocks that occur at the base of the Columbia River basalts are palagonite tuff breccias. He discussed variations in structure produced when Columbia River lavas entered lakes and suggested the use of these structures in determining the direction of flow of lava. A typical pillow-palagonite complex from the Columbia River basalt is best exposed in the road cut about two miles south of Vantage on the eastern side of the Columbia River (Pl. 1 A, $1 \mathrm{~B})$.

FULLER (1931, p. 282) pictured the origin of such foreset bedded breccias as follows:

"The breccia is formed locally of granular fragments of vesicular and ropy sideromelane (clear basalt glass), but as a rule it has been almost completely altered to the yellowish palagonite. The most striking characteristic of the fine breccias is their content of coarse masses of lava lying predominantly in diagonal streaks, which are roughly parallel and have a primary dip toward the north of about 30 degrees. The streaks are composed either of solid basalt or of a series of ellipsoidal or slag-like masses, which are selvaged with glass to a depth of at least a half an inch. With palagonitization their margins blend with the surrounding breccia. These dark masses of lava, contrasting strongly with the yellowish matrix, give the horizon a marked resemblance to foreset bedding ... ».

WATERS (1960) presented additional observations on the problem, and stated that pillow palagonite tuffs and similar structures were developed, especially at the base of the intracanyon flows that have displaced rivers from their beds. He also used them in determining the direction of flows.

MaCkIN (1961) described the occurrence of pillow-palagonite breccia in the Yakima Basalt, where some flows (for example Ginkgo flow) advanced into lakes.

\section{Pillow-palagonite Tuff Breccia from the Oregon Coast}

Submarine flows of Eocene and Miocene age include extensive palagonite tuff breccia complexes along the Oregon coast. They have been mentioned by WATERS $(1955,1960)$. Recently, SNAVELY and WAGNER 
(1962) made a comprehensive study of these volcanics and reported that submarine volcanics of upper Eocene alkalic basalts produced pillow-palagonite complexes along the central Oregon coast.

\section{Petrography}

The writer visited several localities of pillow-lava palagonite tuff breccias in the Columbia River basalt, first with Hoover Mackin and subsequently to collect material for a detailed study. The writer also visited pillow-palagonite complexes along the central and southern Oregon coast at Dr. Water's suggestion. During these visits, observations were made of the nature and origin of palagonite complex and of the various aspects of aqueous chilling and submarine volcanism. In addition, the writer has studied dredged samples from the Pacific Ocean collected by oceanographic expeditions conducted by the Scripps Institution of Oceanography. The petrographic descriptions presented below are typical examples of palagonite tuffs. They were chosen and arranged in an order calculated to best illustrate the results of post-eruptive processes of palagonite tuffs.

\section{Petrography of Palagonite Rocks from the Pacific Coast}

Palagonite Tuff Breccia from the Columbia River Basalt. - A fine example of palagonite tuff breccia from the Columbia River basalt was obtained from the outcrop south of Vantage (Pl. 1 A, 1 B) described earlier. A small slab taken from the same outcrop shows that finer fragments are largely composed of dark gray sideromelane (Pl. $1 \mathrm{C}$ ). The structures observed in the slab are due to perlitic and concoidal fracturing. The yellowish matrix is palagonite, the primary alteration products of sideromelane. Within the palagonite small pellets of sideromelane and white patches of carbonate replacement may be discerned.

In thin sections the basaltic glass sideromelane contains euhedral to subhedral olivine and plagioclase crystals. Along the margins, sideromelane has been transformed to palagonite complex. As in typical palagonitization, the passage from the fresh vitreous and transparent interior of the sideromelane fragment to the outer margin is marked by a characteristic change in color. The transformed material is yellow and in some cases, brownish-yellow. The alteration of glass leading to the palagonite had absolutely no effect on the marginal mi- 
crolites (plagioclases and olivine) which were originally present in the sideromelane (PI. 1 D). Some sections show the development of fibropalagonite with incipient development of colorless crystals. Zeolites, analcite and probably phillipsite are the important alteration products of palagonite. Calcite replacement of palagonite in all stages is noticeable (Pl. $1 \mathrm{E})$.

$\mathrm{X}$-ray studies of yellowish-brown palagonite material reveal the presence of goethite, nontronite, montmorillonite, olivine and carbonate, which is essentially calcite (BoNATTI, personal communication).

The average water content of the palagonite tuff is about 32 percent (PeAcock and Fuller, 1928, p. 375). The specific gravity determination of a few selected samples varies from 2.4 to 2.6 .

Pillow-palagonite Tuff Breccia from the Oregon Coast. - A typical palagonite tuff outcrop from the central Oregon coast and a hand specimen from the same outcrop are shown in Plate 2 A, 2 B. Vitreous particles of sideromelane can rarely be distinguished from the matrix of this rock. However, the characteristic color of palagonite is easily observed. Unusual steel-gray concentrations of minerals are also prominently visible.

In thin sections the rock is a palagonite tuff. Small grains of sideromelane are present. Some of the fragments show little or no alteration and are free from inclusion of microlites of early formed minerals. In some sideromelane fragments, clear fresh subhedral to granular olivine stands out in the opaque base of the glass. Several fragments of sideromelane also contain rather fresh plagioclase. Zeo. lites with radial patterns and crosses of phillipsite are noticeable in the sideromelane and in the decomposed palagonite. Where decomposition has been pronounced, a mesh work of zeolites and reddish brown patches of iron oxide with nontronite are seen. In addition, there are black opaque concentrations of iron and manganese oxide which show a tendency to concentrate along certain planes. In places, the palagonite itself shows extreme alteration with segregation of opaques and weakly birefringent zeolites (phillipsite and probably natrolite) and montmorillonite.

Some sections show replacement by calcite, which also may be pseudomorph olivine. Patches of carbonate in the sideromelane itself are shown in Plate $2 \mathrm{C}$. X-ray determination of the sample shows yellowish-red material is mostly goethite with zeolite (phillipsite) and montmorillonite in subordinate amounts. The steel-gray mineral con- 
centration observed in the outcrop and in the hand specimen is iron and manganese oxide. Elsewhere, pronounced alteration of palagonite results in zeolites, montmorillonite and carbonates.

Palagonite Tuff from the Santa Cruz Mountains. - Cummings et al. (1962) describe the occurrence of pillow lava palagonite complex in the Mindigo formation of Oligo-miocene age from the Santa Cruz Mountains in California. The writer studied three thin sections of palagonite tuff which had been kindly loaned by Dr. Cummings. These slides are excellent illustrations of the alteration of palagonite. They show a wide range of alteration; predominantly carbonate which includes calcite and dolomite, together with zeolites. Carbonate replacement of palagonite to a degree resembles orbicular structure (Pl. $4 \mathrm{~A}$ ). In some cases the sideromelane fragment is also partially replaced by carbonates and such a replacement does not affect the laths of felspar included in the sideromelane (Pl. 4 C, 4 D). In some parts of the section, a greenish-gray variety of basaltic glass shows vermicular growth of carbonate (Pl. $4 \mathrm{E}, 4 \mathrm{~F}$ ). In addition, black opaque segregations, probably $\mathrm{Fe}$ and $\mathrm{Mn}$ oxides in the form of patches, are noticed. These black patches are concentrated where extensive carbonate has formed, as well as within the plagonite (Pl. $4 \mathrm{~B}$ ). Sometimes the opaque ore and palagonite contain within them white patches with incipient outlines of rhombs, which are probably dolomite.

\section{Petrography of Palagonite Tuff Breccias from the Pacific Ocean}

Manganese Nodule from the Mendocino Escarpment. - Several boulders of basalt and manganese nodules were dredged from the top of Mendocino escarpment during the Fan Fare expedition by Scripps Institution of Oceanography. The sample to be described was obtained at a water depth of $1260 \mathrm{~m}$ at $40^{\circ} 23^{\prime} \mathrm{N}$ and $127^{\circ} 59^{\prime} \mathrm{W}$.

The hand specimen has a dark brown crust of manganese and iron oxides. Fragments of basalt, protruding through the crust give the appearance of nodes. In the crust, yellowish-brown patches are visible (Pl. $3 \mathrm{~A})$. The cut section of the hand specimen shows it is a palagonite tuff-breccia, consisting of fragments of fine-grained compact basalt of various shapes and sizes in a yellowish-gray and bright yellow palagonite matrix. Fragments of fine sand-size vitreous black glass occur within the palagonite matrix. The yellowish-gray matrix on the outer margin is considered to be altered palagonite. 
In thin sections, the fragments of basalt show the presence of glomer-porphyritic aggregate of feldspar in the form of needles and fine laths. The feldspar is relatively fresh and is labrodorite. Granular pyroxene and olivine along with tachylytic glass form interstitial material. Subhedral crystals and aggregates of pyroxene are the dominant mafics. Both pyroxene and the small amount of olivine present show little or no alteration. The tachylytic glass shows various stages of devitrification and it is loaded with bundles of crystal needles and rods of black opaque concentrations of iron and manganese oxide? These needles and rods form a crude dendritic pattern and show a tendency to migrate outward and concentrate along the margins of the fragments. The marginal palagonite which forms the cementing material for the fragments also shows decomposition. The products of this decomposition are black opaque iron and manganese oxides in addition to zeolite, which is phillipsite? and montmorillonite. The texture of the basaltic fragments varies from hyalopilitic to intersertal.

The yellowish matrix shows sideromelane fragments which are cemented by their own alteration product, palagonite. These fragments are dark brown and many are free of microlite inclusions. Within the sideromelane there are reddish-brown segregations in the shape of specs, globulites and semi-circular rings, which resemble botryoidal forms (Pl. $3 \mathrm{C}$ ). Palagonite in thin section is deep brownish-yellow, sometimes resembling amber and forms a uniform margin around larger fragments of sideromelane and completely replaces smaller fragments. The margins where the sideromelane grades into palagonite are darkened with a concentration of iron bearing globulites. Alteration of palagonite itself shows a segregation of black and reddishbrown patches which are probably iron and manganese oxides. In addition, faintly birefringent zeolites are observed.

Manganese Nodule from the South Pacific. - The sample described below is a typical manganese nodule dredged from the south $\mathrm{Pa}$ cific Ocean at $25^{\circ} 31^{\prime} \mathrm{S}, 85^{\circ} 4^{\prime} \mathrm{W}$ at a depth of $920 \mathrm{~m}$. Its thick crust of manganese and iron oxide has a broken surface on the side showing a distinctive nucleus of brownish-yellow material which is palagonite tuff (Pl. 3 E). Grayish-black manganese and iron oxide are also seen in the form of vein-like ramifications within the palagonite and sometimes completely enclose the grains of palagonite. Under microscope, the grayish-black material is very similar to the crust and to the black opaque concentration of iron and manganese oxide describ- 
ed above. It is one of the decomposition products of palagonite and sideromelane which has concentrated along planes giving the appearance of vein-filling.

Yellowish palagonite, similar to that described in the nucleus of the above nodule, is invariably recorded as a nucleus in several of the manganese nodules described in literature. However, the nucleus of some of the nodules consists of zeolites and montmorillonite or essentially zeolites as seen in the "Horizon » nodule described below.

The "Horizon" Manganese Nodule from the North Pacific. - The "Horizon " manganese nodule is the biggest nodule recovered by the Scripps Institution of Oceanography. It weighs about $62 \mathrm{~kg}$ and is one meter long. It was dredged from the north Pacific at $40^{\circ} 14^{\prime} \mathrm{N}, 155^{\circ}$ $05^{\prime} \mathrm{W}$, about 1500 miles north of Hawaii at a depth of 5500 meters. A cross section of the nodule is shown in Plate 3B. This specimen has figured in several descriptions of manganese nodules (GoLDBERG and ARRHENIUS 1958, MENARD 1960, GoldBERG 1961, MERo 1962). It consists of dark thick crust of manganese and iron oxide, enclosing light colored material which is mainly composed of indurated crystals of zeolite.

Microscopic study of a sample from the nucleus shows that it consists predominantly of phillipsite which is growing out of palagonite. Examination of the manganese.crust shows that phillipsite and palagonite are also associated with manganese and iron oxide. They are scattered as small aggregate concentrations in the manganese crust as white patches.

Palagonitized Basalt from the Experimental Mohole Drilling. Basalt is found in hole EM7 from the experimental deep-sea drilling of the Mohole project at the Guadalupe site 150 miles off the coast of Baja California. In hole EM10, palagonitized basalt in contact with partially dolomitized sediment is found. RIEDEL et al (1961) presented a description of cores and ENGEL and ENGEL (1961) described the composition of basalt cored in hole EM7.

Basalt, glassy along one edge was recovered in EM10 Run 1. In hole EM10 Run 2 a ten $\mathrm{cm}$ core was obtained. The upper $0-3 \mathrm{~cm}$ is highly indurated sediment, yellowish-gray $(5 \mathrm{Y} 7 / 2$, National Bureau of Standard Color Chart) with dolomite and zeolite in contact with palagonitized basaltic glass. A detailed petrographic description of these samples and the significance of the occurrence of basalt and palago- 
Y. Rammohanroy Nayud - Palagonite tuffs (Hyaloclastites) and the products of post-eruptive processes.

$1 \mathrm{~A}$

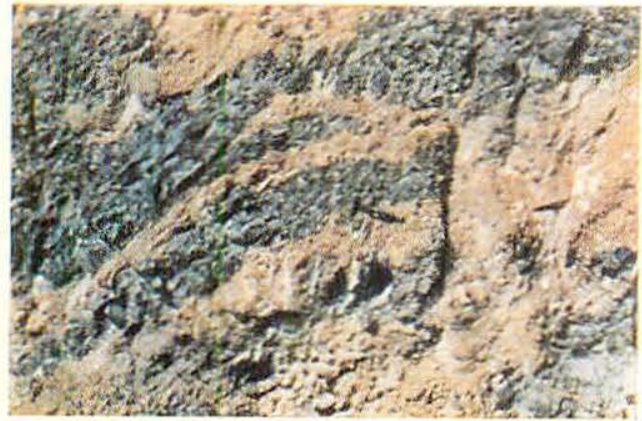

$1 \mathrm{C}$

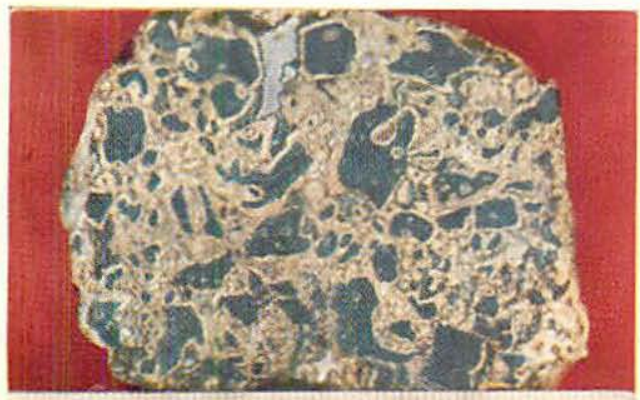

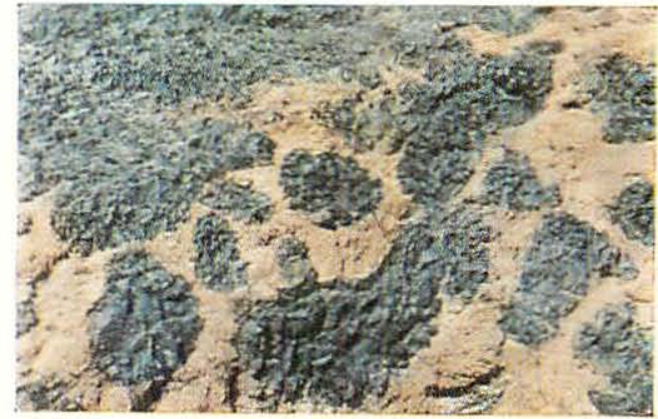

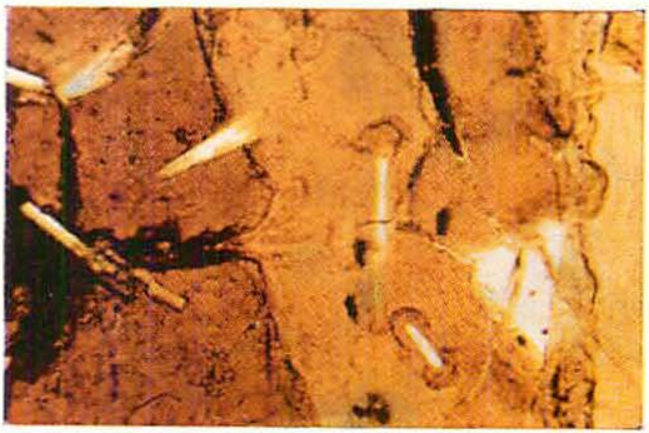

I D

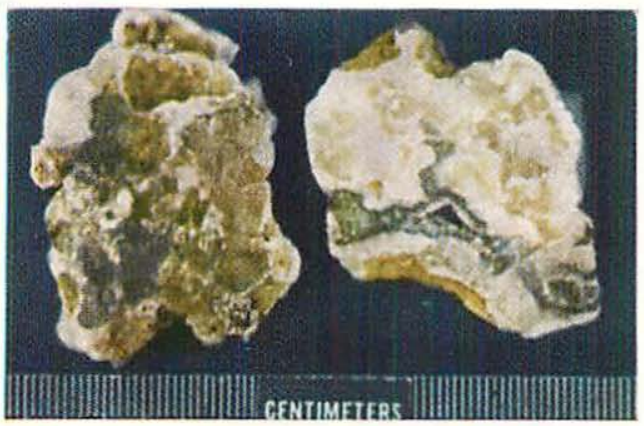

$1 \mathrm{E}$ 
Plate 1 - Pillow-palagonite complex from the Columbia River basalt. 1 A: An horizon of pillow-palagonite complex with well developed foreset structures exposed in a highway cut 2 miles south of Vantage on the eastern side of the Columbia River. Note elongated masses and streaks of dark gray solid basalt in the yellowish palagonite tuff breccia.

1 B: Another view of the same horizon taken about 100 yards to the right of $1 \mathrm{~A}$. Note the excellent development of pillows in the palagonite breccia matrix. A transition between the basal horizon of pillow lava and an overlying parent flow on the top are also exposed. Pick in the center of both pictures gives the scale.

$1 \mathrm{C}$ : A slab of palagonite tuff breccia from the same horizon. (See $1 \mathrm{~A}$ and (B). It shows brecciated fragments of dark gray vitroeous sideromelane of varying sizes set in the matrix of palagonite. Scale in $\mathrm{cm}$.

$1 \mathrm{D}$ : Photomicrograph of thin section of palagonite tuff from the slab (see $1 \mathrm{C}$ ) showing dark brown variety of basaltic glass, sideromelane, including labradorite crystals on the left. On the margins of the sideromelane, note deep golden palagonite, the primary hydration product of sideromelane. Also note hydration of basaltic glass leading to palagonite had no effect on the microlites of feldspar, originally present in the sideromelane; concentration of dark opaques in semicircular rings are also seen in the obscurely birefringent pale colored palagonite on right. Plane light. X 150.

$1 \mathrm{E}$ : Alteration of palagonite into two kinds of calcite. Black calcite in the lower right. Note the presence of yellowish palagonite in calcite and concentration of dark gray opaque material. 
Y. Rammohanroy Nayudu - Palagonite tuffs (Hyaloclastites) and the products of post-eruptive processes.

$2 \mathrm{~A}$
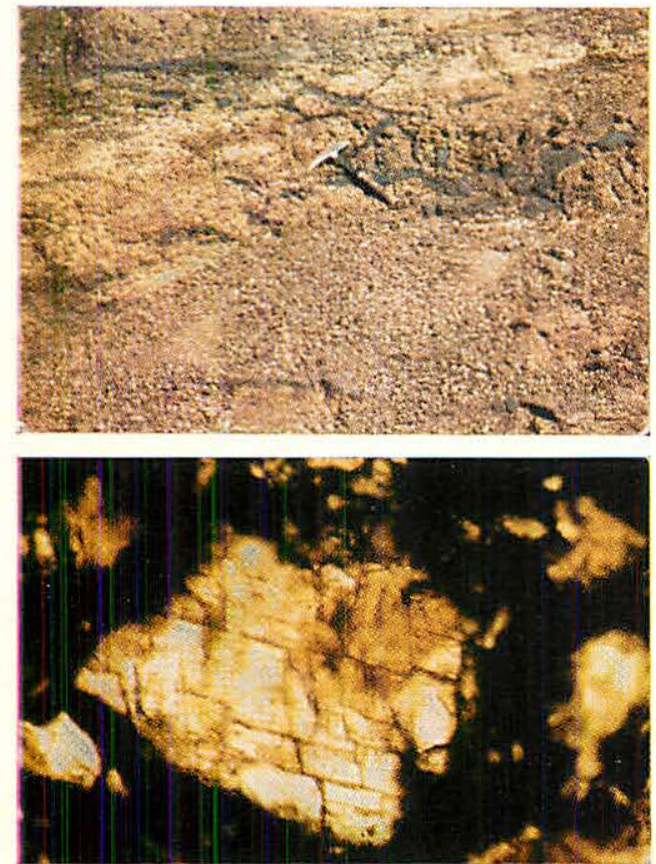

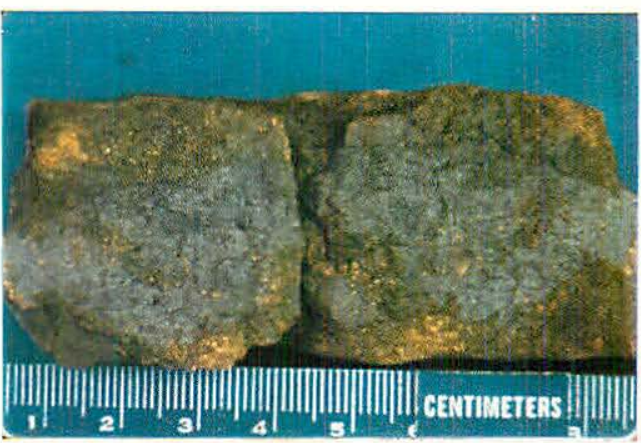

$2 \mathrm{~B}$

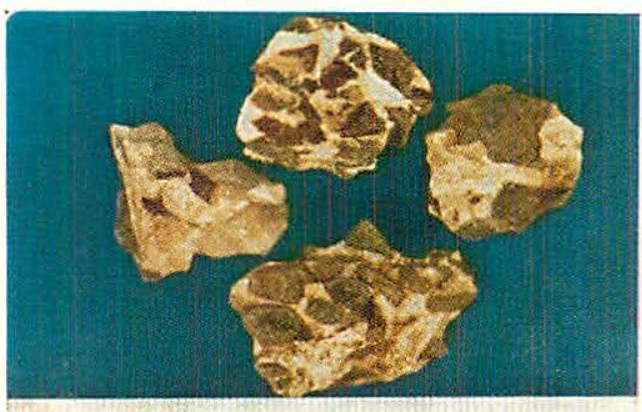


Plate 2-Palagonite tuff from Oregon coast. 2 A: Palagonite tuff outcrop along the central Oregon coast. Note the steel-gray ferromanganese mineral concentrations and the white patches of zeolites and carbonates.

2 B: Hand specimen from the outcrop (see 2A) showing typical color of palagonite and thin coating or concentration of ferromanganese oxides.

$2 \mathrm{C}$ : Photomicrograph of thin section of palagonite tuff from central Oregon coast showing carbonate replacement of palagonite and sideromelane. Crossed Nicols. X 150 .

2 D: Fragments of basalt cemented by calcite which is alteration product of original falagonite cement: scale in $\mathrm{cm}$. 
Y. Rammohanroy Nayudu - Palagonite tuffs (Hyaloclastites) and the products of post-eruptive processes.
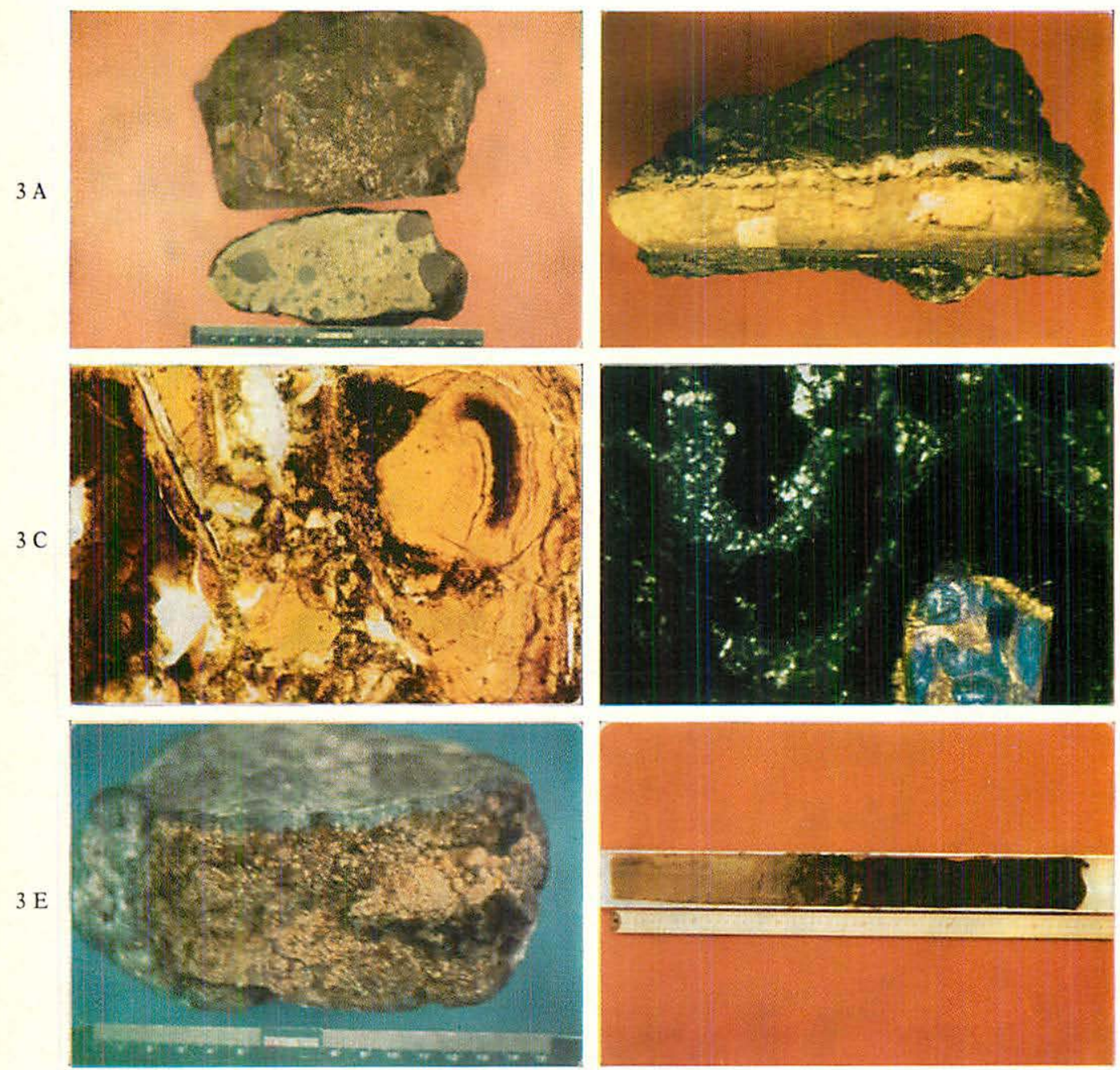
Plate 3 - Manganese nodules and deep-sea sediment core from Pacific Ocean. 3A: Manganese nodule from the Mendocino Escarpment. Slab cut from the nodule shows that the central part consists of palagonite tuff breccia. Palagonite with its characteristic yellow color forms the matrix for the basalt and sideromelane fragments.

3 B: Cross-section of the "Horizon" Nodule from north Pacific. Crust of manganese and iron oxides surround nucleus consisting of zeolite (phillipsite). Small patches similar to the core are also scattered throughout the crust.

3 C: Photomicrograph of thin section of palagonite tuff shown in $3 \mathrm{~A}$ from Mendocino Escarpment. Note the migration and segregation of iron and manganese oxides; the concentric structures (botryoidal) within the deep yellow palagonite; and dark patches of opaques in and around the sideromelane (basaltic glass) on the left. White patches of felspar and zeolites are also seen. Plane light. X 150.

$3 \mathrm{D}$ : Photomicrograph of thin section of palagonite tuff, Oahu, Hawaiian Islands. Fragments of isotropic sideromelane consist of fresh olivine crystals. Alteration of palagonite rims of the sideromelane glass results in birefringent zeolites, white, which forms the matrix between the fragments. Crossed Nicols. X 150 .

$3 \mathrm{E}$ : Manganese nodule from south Pacific with a nucleus of yellowish palagonite tuff, which contains veins and segregations of ferromanganese oxides.

3 F: North Pacific deep-sea sediment core (CK)2. Note the marked discontinuity at $22 \mathrm{~cm}$ and the white zeolite patches between $24-32 \mathrm{~cm}$ in the dark gray sediments. Zeolites are associated with the dark gray ferromanganese micronodules and yellowish-red palagonite grains. Scale in $\mathrm{cm}$. 
Y. Rammohanroy Nayudu - Palagonite tuffs (Hyaloclastites) and the products of post-eruptive processes.

$4 \mathrm{~A}$

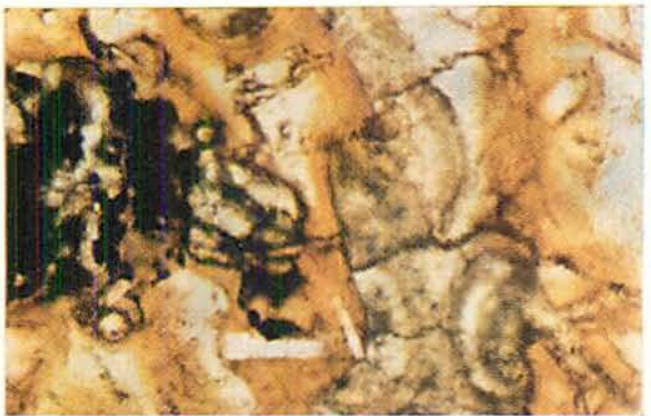

$4 \mathrm{C}$

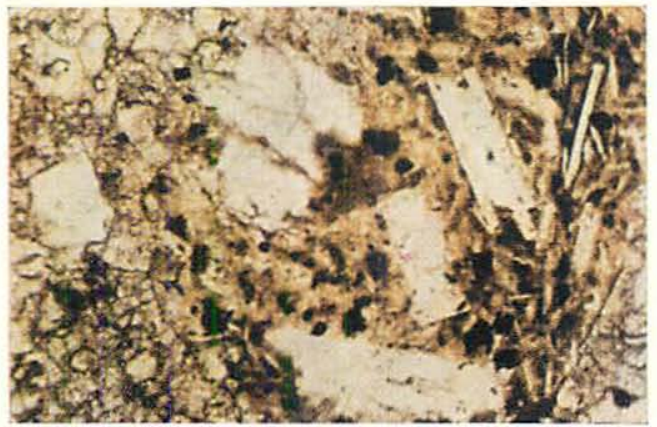

$4 \mathrm{E}$

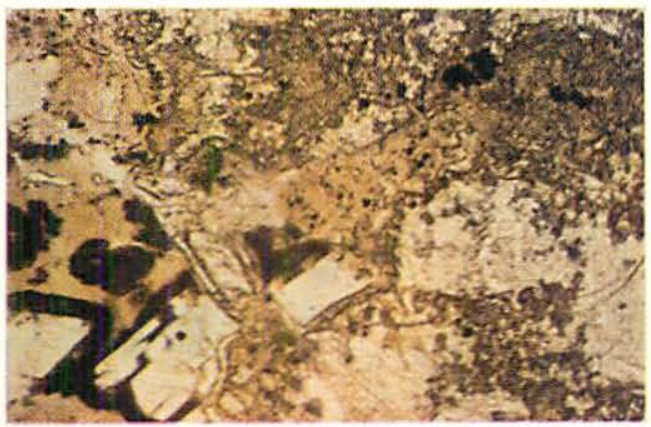

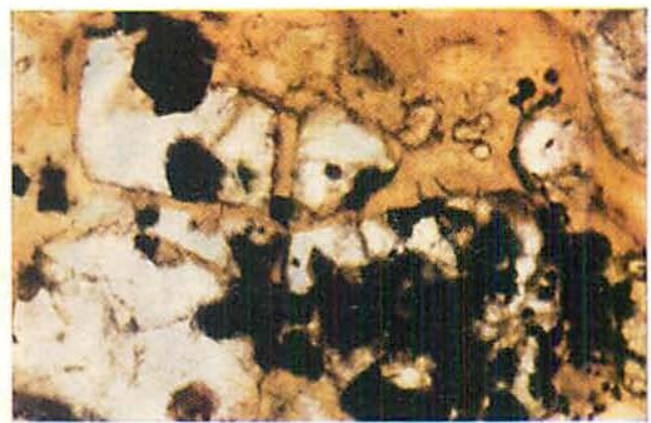
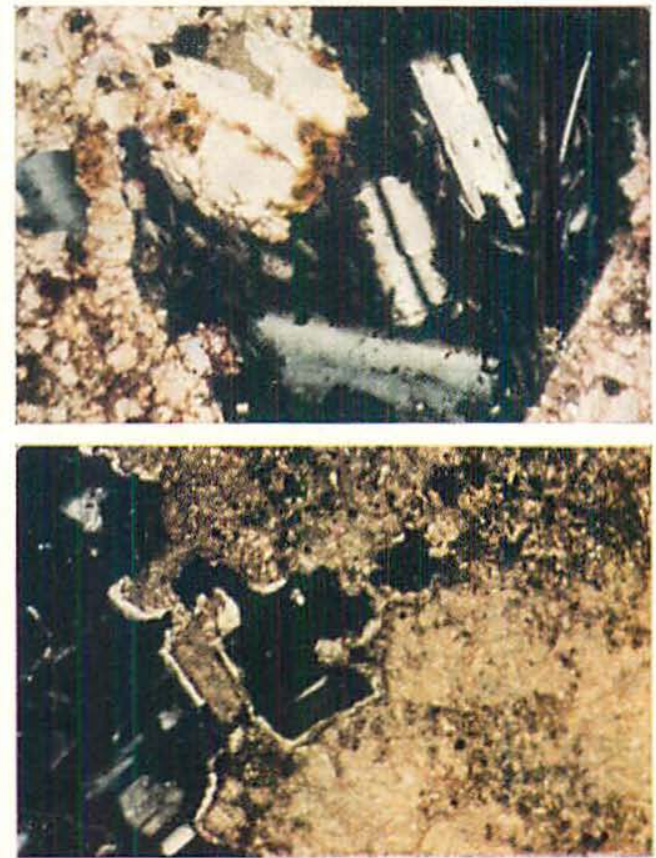
Plate 4-Carbonate replacement of palagonite tuff from Santa Cruz mountains, California. $4 \mathrm{~A}$ : Photomicrograph of thin section of palagonite tuff from Mindigo formation showing replacement of yellowish palagonite by carbonate and development of orbicular structures. Note concentration of dark opaques with carbonate in the palagonite on the left. Plane light. X 150.

$4 \mathrm{~B}$ : Photomicrograph of thin section showing carbonate replacement of palagonite and concentration of opaques within the palagonite and on the margins of carbonate, white. Plane light. X 150.

$4 \mathrm{C}$ : Photomicrograph of palagonite tuff showing laths of plagioclase feldspar in the fragment of glass and carbonate replacement. Seen as homogeneous mass. Plane light. X 150 .

4 D: Same as 4C, under crossed Nicols. Note the replacement of palagonite tuff by carbonate around the basaltic glass fragment. Carbonate replacement of glass as well as unaffected plagioclase fragment can be seen at center left. X 150.

$4 \mathrm{E}$ : Photomicrograph of thin section of basaltic glass showing plagioclase enclosed in it and vermicular growth of carbonate. Plane light. X 150.

4 F: Same as $4 \mathrm{E}$ under crossed Nicols. Carbonate with small specks of black opaques (probably ferromanganese oxides) seen in the lower right. $X 150$. 
Y. Rammohanroy Nayudu - Palagonite tuffs (Hyaloclastites) and the products of post-eruptive processes.

$5 \mathrm{~A}$
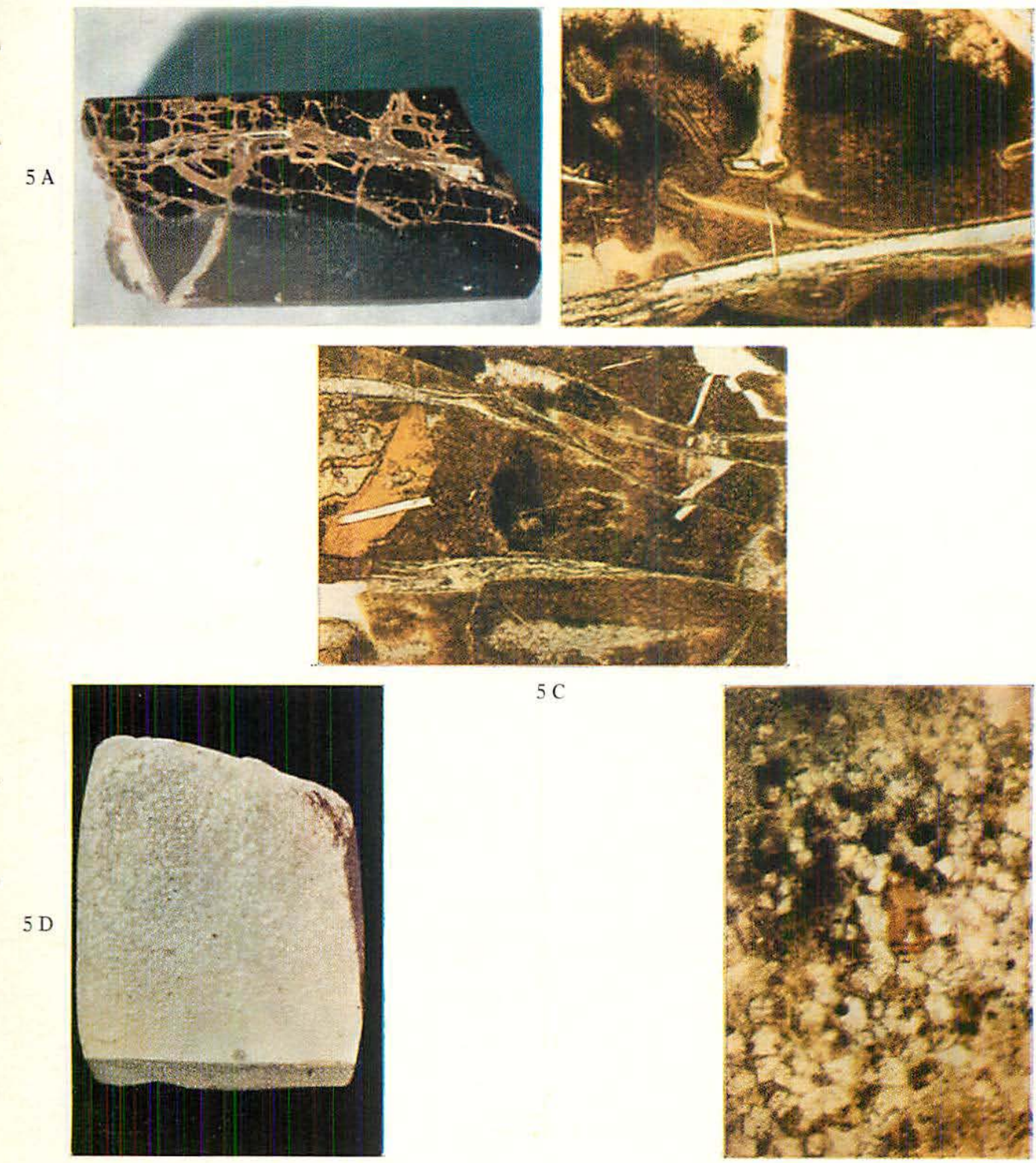

5 C

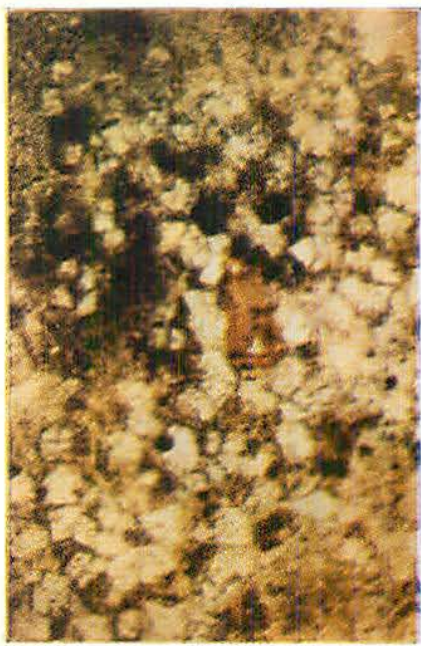


Plate 5 - Palagonitized basalt from experimental Mohole drilling. $5 \mathrm{~A}$ : Palagonite tuff breccia in contact with glassy basalt from the experimental Mohole drill hole, showing yellowish-red, waxy palagonite. Note vein-like white patches in the palagonite.

5 B: Photomicrograph of thin section of palagonite tuff breccia (see $5 \mathrm{~A}$ ) showing typical palagonitization of sideromelane. Later alteration of palagonite results in zeolites and carbonate (calcite and dolomite). Plane light. $\mathrm{X} 150$.

5 C: Another photomicrograph of thin section of palagonite (see $5 \mathrm{~A}$ ). Shows replacement of palagonite by zeolites and carbonate (calcite and dolomite) and tridymite or opal? seen as white patches or vein filling. Note deep yellow palagonite on the left. Plagioclase lath is unaffected by palagonitization. Plane light. X 150.

5 D: Gray basaltic glass fragment in contact with carbonate. Note reddishbrown specks, probably original palagonite within the carbonate and along the right margin.

$5 \mathrm{E}$ : Photomicrograph of thin section of fragment of basaltic glass in contact with carbonate (see $5 \mathrm{D}$ ). Note replacement of yellowish-brown palagonite by carbonate (calcite and dolomite); and concentrations of yellowish palagonite on the margins of calcite and dolomite rhombs. Also note yellowish fragment with dolomite in center and concentrations of black opaques. 
nitized basalt forms a separate paper (NAYUDU in preparation). Some extracts pertinent to the present problem are drawn from the above paper.

In hand specimen, palagonitized basalt ( $\mathrm{Pl}$. 5A) has the appearance of breccia with broken fragments consisting of angular to subangular, sand to granule size dark variety of glass. Between the fragments there is a dirty yellowish-red cementing base somewhat waxy in appearance, which is palagonite. There are numerous veinlets visible in the brecciated part, one of which is seen in the solid basalt. Most of the veinlets contain colorless minerals which appear to be replacing the cementing palagonite.

In thin section most of the dark fragments of the brecciated part are composed of yellowish, transparent clear sideromelane. Along the fractured edges there is an intense palagonitization. In some places, the entire fractured fragment of sideromelane is completely altered to gel-like yellowish-red palagonite material. Alteration subsequent to palagonitization seems to produce carbonates (calcite and dolomite?), zeolites and cryptocrystalline silica (tridymite? or opal?). In the center of the vein-like cementing palagonite, more carbonate is noticed, with well developed rhombs of calcite and dolomite (Pl. 5B). Replacement origin of carbonates and zeolites is inferred from the presence of slightly yellowish palagonite within the carbonate and its concentration along the rhombs' margin. The exact stages of alteration are not at once obvious. However, from the petrographic evidence it is inferred that zeolites were the earlier formed and carbonate last. Thus carbonate together with zeolite and crypto-crystalline silica (tridymite or opal?) are the colorless minerals which are the products of post-eruptive processes of palagonite and are seen as veinlets or patches (Pl. $5 \mathrm{~B}, 5 \mathrm{C})$.

In drill hole EM10 another remarkable sample was recoverd. It consists of a thin fragment of dark basaltic glass in contact with light brown carbonate. There are reddish-golden patches along the margin (Pl. 5 D).

The thin section shows a clear pale variety of basaltic glass, sideromelane, with laths of plagioclase. The sideromelane along the margin shows patches of slight palagonitization. It grades into a light yellowish-red material (probably palagonite). Within this material, in contact with the sideromelane, small specks and incipient rhombs of carbonate appear as islands. Along the margins of the sideromelane 
there are isotropic zeolites as well as carbonates. A few millimeters away from the contact are numerous rhombs of dolomite.

In the writer's opinion, the pale yellowish-red material is probably altered palagonite. Some of the rhombs show remnants of altered palagonite as a core. A material similar to the core of the rhombs also forms the cement for individual rhombs (Pl. $5 \mathrm{E}$ ). Development of rhombs progressively increases away from the contact, where fibrous and radial growths of carbonate (calcite) are cut by isolated dolomite rhombs.

\section{Discussion}

The foregoing petrographic description of palagonite tuff breccias shows that manganese minerals, zeolites and carbonates are some of the most important products of the post-eruptive processes of palagonites. A brief discussion of these minerals is presented below.

Manganese Minerals. - This study and additional available data indicate that manganese nodules are associated with volcanic material, especially palagonite tuffs. The thin section study of palagonite tuffs, with or without a manganese crust, established that they are primary products resulting from the aqueous chilling of basalt. It is further shown that there is a characteristic segregation of dark globulites, patches and concentric (botryoidal) structures (Pl. $3 \mathrm{C}$ ). These structures suggest that migration and segregation of metallic elements take place on a microscale and seem to be initiated after the relaxation of palagonitization, i.e. post-depositional changes. Thus there are good reasons to believe that during the palagonitization of sideromelane the absorbed water (a maximum of 30 percent) is probably present either as a colloidal or a simple solvent. The process is accompanied by the oxidation of iron and probably other elements present in the sideromelane, which represents nearly the total com. position of basalt. Consequently these compounds would start to precipitate from the unstable palagonite.

Furthermore, the writer, in his studies of the deep-sea sediment cores from the north Pacific observed several manganese rich sections in the cores. A typical core is Chinook (CK) 2 located north of Hawaii in which at $22 \mathrm{~cm}$ there is a marked break in sediment continuity. From $22 \mathrm{~cm}$ to the bottom $(56 \mathrm{~cm})(\mathrm{Pl} .3 \mathrm{~F})$ it is rich in micronodules of ferromanganese oxides and zeolite (phillipsite). These micronodules 
are associated with nontronite? and palagonite. Some grains occur as bright red pellets with concentric dark rings which are probably ferromanganese oxides. Under the microscope, these sediments look very similar to the crushed manganese crust and palagonite core of the nodule from the south Pacific.

In addition, several red clay areas in the north Pacific contain yellowish-red palagonite associated with ferromanganese oxides. Most of the palagonite grains contain segregations of ferromanganese oxides. Thus it appears that some of the red clays and the ferromanganese oxides associated with them are genetically related to the palagonite.

GoLDBERG (1961) in discussing manganese nodules states that the exotic nature of these minerals has inspired a number of hypotheses for their mode of origin. MURRAY (MURRAY and RENARD 1891) was the first to suggest that the manganese and iron of the nodules are derived from volcanics. Recently, PETrERsson $(1945,1955,1959)$ suggested that manganese is derived from pyroclastics decomposing on the sea floor. On the other hand, GoLDBERG and ARRHENIUS (1958) and GoLDBERG (1961) advocate the theory that most of the manganese is derived from sea water. ARRHENIUS (1963) states that regardless of the ultimate source and mode of transportation, the transfer of manganese from sea water takes place by catalytic oxidation of manganous ions by colloidal ferric hydroxide at the sediment water interfaces. At present the theory proposed by Goldberg and Arrhenius is the most widely accepted. They further suggest that the volcanic association of manganese nodules indicates a low rate of deposition and does not imply a genetic relationship.

A complete discussion of the divergent views is not within the scope of this paper and a detailed paper on manganese nodules is in final preparation (BONATTI and NAYUDU). However, a survey of the related literature shows that several manganese deposits are associated with volcanic submarine flows, especially with pillow lavas and pyroclastic tuffs. TALIAFERRO and HUDSON (1943) described manganese deposits which are associated with submarine volcanics in the Franciscan formation of California. Another excellent example of such deposits is the Olympic Peninsula, in the state of Washington (PARK, 1946, 1956). Park noted that the manganese deposits in this area are more abundant at the top of the flows and at some places filling the interspace between pillows. He suggested that the manganese may have been extracted from the lavas, which are of submarine origin, and he visualized hot sea water rushing through the lava reacting with 
it and leaching manganese along with iron, silica and calcium. $\mathrm{He}$ further presented rough calculations to show that the amount of manganese in basaltic rocks is more than sufficient to supply the manganese in the observed deposits: on the assumption that the average basalt contains 0.17 to 0.31 percent $M n O$ and assuming that only 0.01 percent $\mathrm{MnO}$ is removed, alteration of a cubic mile of basalt of specific gravity of 2.9 would yield about $1,333,980$ tons of $M n O$, or a flow one mile square and 100 feet deep would yield about 25,264 tons of $\mathrm{MnO}$.

KRAUSKOPF (1956) reviewed the mechanism of dissolution and precipitation of manganese from submarine volcanics and presented additional experimental data. He closely followed Park's idea and proposes a rather attractive hypothesis. According to him, basic lavas entering the sea water would be expected to liberate acid gases, resulting in acid solutions, which should dissolve iron and manganese while circulating through the system. Continued mixing of the sea water would neutralize the acid and provide dissolved oxygen to precipitate the iron first. By the time the solution has traversed through the lava pile, it would attain the approximate alkalinity and oxygen content of normal sea water. The conditions would be ideal for manganese precipitation. He further states that during the process, silica would dissolve from the hot lava. Hence, the particular manganese compounds formed would vary with local conditions. Krauskopf's hypothesis seems to be in good agreement with general features of manganese deposits associated with submarine volcanics.

According to GoLDBERG (1961) tetravalent manganese which is the major component of ferromanganese minerals is not found in sea water. If we assume that the sea water in the palagonite is present in the form of a colloidal solvent, then herein may be the source for the colloidal iron oxide necessary as a catalytic agent to form and carry the tetravalent manganese in the ferromanganese minerals of nodules.

It is quite possible that the hypothesis suggested by Krauskopt is a more plausible explanation; or the precipitation of manganese may take place by a combination of both processes. The writer is not in a position at this stage to discuss the merit of these hypotheses in detail nor to suggest a preference.

The extraordinary association of manganese minerals with such metals as nickel, cobalt, copper, zinc and lead would have a direct relationship to the composition and nature of the original magma. It 
would also be enriched by the elements in the sea water which is absorbed during palagonitization.

In final analysis, the writer strongly believes that palagonitization is the critical first step in the formation of ferromanganese minerals. The major part of the ferromanganese minerals associated with nodules have a genetic relationship to palagonites.

Zeolites. - Petrographic studies of palagonite tuffs discussed in this report show that several kinds of zeolites result from the decomposition of palagonite tuffs, phillipsite being the most common in the rock studied.

In the \& Horizon nodule it was shown that the light colored mineral which forms the nucleus is mostly phillipsite and is associated with palagonite and montmorillonite (even the manganese crust contains segregations of phillipsite and palagonite) ( $\mathrm{Pl}$. 3B).

GOLDBERG (1959) and many other workers have demonstrated that the association of montmorillonite and zeolite suggests an alteration of basic volcanics. The petrologic evidence presented in this report shows that this association is commonly derived from the alteration of palagonite.

Furthermore, MaTHEWS $(1961,1962)$ described the occurrence of bedded palagonite vitric tuffs and breccias with manganese encrusting from an abyssal hill on the floor of the North Atlantic. He states that zeolites, montmorillonite and calcite are associated with the alteration products of palagonite and vesicular basalts. Also, manganous oxide within rocks was redistributed as « pelagite" (manganese). He further suggests that these alterations have taken place at the lowest temperature (less than $200^{\circ} \mathrm{C}$ to about $0^{\circ} \mathrm{C}$ ). The data presented by Mathews seems to be consistent in many respects with the main thesis of this paper. However, the writer feels that the results presented herein and in a previous paper dealing with the mechanism of submarine eruptions leading to the buildings of seamounts (NAYUDU 1962a) may help to clarity the reasons for the associations noted in Mathew's paper.

On the islands of Hawaii and Oahu in the Hawaiian chain, phreatomagmatic eruptions have produced extensive palagonite tuffs (Koko Crater in Oahu and Kopoho Crater in Hawaii). The main alteration products of palagonite are zeolites (phillipsite and analcite?) (Pl. 3D).

Several north Pacific deep-sea sediment cores show a high concentration of zeolites, mainly phillipsite. Their genetic association with 
palagonite showing different stages, including cross structures and display of extensive intergrowths developing out of palagonite have been noticed by the writer. In the deep-sea core «Chinook 》 (CK)2, discussed earlier (page 12) there is a marked discontinuity at $22 \mathrm{~cm}$ depth in the core. Below this discontinuity from $2430 \mathrm{~cm}$, phillipsite, in the form of white patches, is concentrated with palagonite and ferromanganese micronodules ( $\mathrm{Pl} .3 \mathrm{~F}$ ). Most of the crystals of phillipsite including cross shaped ones show genetic relationship to palagonite. Sediment cores taken south and southeast of Hawaii display incipient to well developed zeolites: phillipsite, harmotome, natrolite and clinptolite? which are associated with palagonite and nontronite.

ARRHENIUS (1963 in press) stated that high concentrations of zeolites at the active sediment water interface suggest that they might have been derived from the sea water. BonatTI and ARRHENIUS (in preparation) by their detailed X-ray determinations showed that phillipsite of the south Pacific sediments is always associated with palagonite and nontronite, and that the basic unit of zeolite crystals is directly derived from palagonite.

Carbonates. - In the petrographic description of different occurrences of palagonite it has been shown that calcite is associated with the alteration of palagonite.

Complete replacement of palagonite by carbonate was observed in the form of white patches in the palagonite tuffs from the Columbia River basalt. In some instances, alteration of palagonite into two kinds of calcite was observed, which includes needles of black calcite concentrations (Pl. $1 \mathrm{E})$. Replacement origin is inferred from the presence of yellowish palagonite in the carbonates.

Peacock and Fuller $(1928$, p. 374) described palagonite breccia that consists essentially of black angular fragments of sideromelane cemented with abundant calcite. Sideromelane is seen to be still fresh with slight yellowish palagonite.

In the Oregon palagonite tuffs, calcite, which is one of the alteration products of palagonite, forms the cement for angular fragments of basalt of the original breccia (PI. $2 \mathrm{D}$ ).

Calcite associated with manganese minerals and zeolites in the Olympic Penisula described by PARK (1946 p. 416) as an alteration of lavas, is probably derived from palagonite tuffs associated with submarine volcanism.

Furthermore, it is suggested that the frequent occurrence of inter- 
calated limestone lenses between submarine lava flows and calcareous mud around pillows may result from the alteration of palagonites.

Carbonate seems to form throughout the alteration process. Its value in the problem of petrogenesis is not fully understood and carbonate is of little value in evaluating the stage of alteration. However, it is invariably associated with zeolites and seems to accompany zeolitization, suggesting that it is probably one of the last minerals to form. This relationship is clearly illustrated both in the palagonite complex from the Santa Cruz Mountains and the palagonitized basalt from the experimental Mohole drilling.

\section{Conclusions}

The petrologic results and discussion herein presented show that carbonates, mainly calcite, as well as zeolites associated with palagonite tuffs, are the alteration products of palagonite. It is shown that phillipsite of the north Pacific is genetically associated with palagonite and is a product of post-eruptive processes. Several manganese nodules recovered from the ocean floor contain nucleus of palagonite tuff or its alteration products montmorillonite and zeolites. From the petrography and petrology of the palagonite tuffs associated with these nodules, and the ferromanganese minerals themselves as well as available data on manganese deposits associated with submarine volcanism, it is proposed that a genetic relationship exists between palagonite tuffs and ferromanganese minerals on the ocean floor. Furthermore, this study shows that some red clays associated with manganese are also alteration products of palagonite tuffs.

Available data suggest that palagonitization is a critical first step for various suggested hypotheses for the dissolution and precipitation of manganese. The exact physico-chemical factors involved are not yet clear. However, the association of zeolites, carbonates and manganese oxides with palagonite suggest a genetic relationship probably controlled by a delicate balance between $p H$ and $E h$ variations. This association of minerals suggests rather highly alkaline conditions ( $p H$ greater than or near to eight) and the entire process seems to be very slow. Research in progress might present additional information. The writer does not offer a magic formula to solve one of marine geology's oldest riddles. The evidence presented shows that important pronounce. ments made by past masters of the problem, like Murray and Pettersson on manganese; Waltershausen, Peacock and Fuller on palago- 
nite, are of great significance if examined in the light of more recent work.

In conclusion, the writer believes that the " exotic " ferromanganese minerals on the ocean floor nodules are inexorably associated with " exotic" palagonites. These palagonites are called exotic by the writer not because they are foreign, but because they are aesthetically beautiful, of such high scientific value in the petrogenesis of submarine volcanics, and of great economic value. If some of the results presented here seem to rebel against conformity, it is not the writer's fault; it is because they are of nature's and not of man's conception.

\section{Acknowledgements}

The writer expresses his sincere gratitude and thanks to Gustaf Arrhenius and William Riedel for their suggestions and encouragement and for providing samples. Sincere thanks are also due to Enrico Bo natti for helpful discussions and X-ray analyses of samples. Thanks are also due to Roy Wadge for preparing the thin sections; to John Harris and Thomas Walsh for their valuable assistance in the laboratory; to all members of the Scripps Institution expeditions who collected the samples; to my wife who aided in the final preparation of the manuscript, and to Lorayne Buck and Berniece Tomczak for typing. The manuscript has benefitted in form and content by the critical reading of H. A. Coombs, J. D. Barksdale, University of Washington, and A. C. Waters, Johns Hopkins University.

This investigation was supported in part by the Office of Naval Research Contract Nonr-477(10). Project NR 083-012 and Contract Number $477(37)$ project $\mathbf{F}(\mathbf{R}, 00403$, and in part by the National Science Foundation Grants G-9407, G-21518, and the writer is indebted for these contributions. 083.012

\section{References}

ARRHENIUS, G., The Seas, Ideas and Observations (in press). Interscience publishers, John Wiley and Sons, New York, 1963.

BUNSEN, R., Ueber die Prozesse der vulkanischen Gesteinbildungen Islands, N. Jahrb. f. Min., 537-884, 1851.

Cummings, J. C., Touring, R. M. and E. R. BrabB, Geology of northern Santa Cruz Mountains, California, California Div. of Mines and Geology Bull. 181, 179-220, 1962.

ENGEL, C. G., and A. E. J. ENGEl, Composition of basalt cored in Mohole project Am. Assoc. Petroleum Geologists Bull., v. 45, 1799, 1961. 
FULLER, R. E., The aqueous chilling of basaltic lava on the Columbia River platean Am. Jour. Sci., 21, 281-300, 1931.

$\longrightarrow$ Concerning basaltic glass, Am. Mineralogist, 17, 104-107, 1932.

- Structural features in the Columbia River lavas of central Washington, a criticism, Jour. Geol., 42, 311-320, 1934.

, Structural features in the Columbia River basalt. Northwest Sciences, 24, 6473, 1950.

GOLDBERG, E. D., Physics and Chemistry of the Earth, 294, 1959.

, Chemistry in the oceans, Oceanography, Pub. no. 67, Am. Assoc. Advancement of Science, Wash., D. C., 1961.

, and G. ARrhenrus, Chemistry of Pacific pelagic sediments, Geochim. et Cosmochim. Acta 13, 153-212, 1958.

KuARTNSSON, G., Arnesinga Saga, Reykjavik, 1943.

KraUSKopp, K. B., Internat. Geol. Cong., 20th, Mexico 1956, Rept., Separation of manganese from iron in the formation of manganese deposits in volcanic association, 1956.

MACKIN, J. HOOVER, A stratigraphic section in the Yakima basalt and the Ellensburgh Formation in south-central Washington, Washington Div. Mines and Geology, Rept. No. 19, 1961.

Mathews, D. H., Lavas from an abyssal hill on the floor of north Atlantic Ocean, Nature, v. 190, no. $4771,158-159,1961$.

- Altered lavas from the floor of the eastern north Atlantic, Nature, v. 194, no. 4826, 368-369, 1962.

MENAPD, H. W., Consolidated slab on the floor of the eastern Pacific, Deep-Sea Research, v. 7, 35-41, 1960.

MERo, J. L., Ocean-floor manganese nodules, Econ. Geology, v. 57, no. 5, 747-767, 1962.

Murray, J. and A. F. Renard, Deep-sea deposits, Rept. Challenger, Exp. London, 1891.

NAYUdU, Y. R., A new hypothesis for origin of guyots and seamount terraces, Crust of the Pacific Basin, Geophys. Mon. no. 6, 1962a.

- Submarine eruption of basalts and the problems of palagonitization, Internat. Symp. of Volcanology, Japan 1962, Abstracts, $1962 \mathrm{~b}$.

NOE-NYGAaRD, A., Subglacial volcanic activity in ancient and recent times (Studies in the palagonite system of Iceland, No. 1) Kgl. Danske, Geol. Selsk, Folis Geogr. Danica, 1, no. 2, Copenhagen, 1940.

Park, C. F., Spilite and manganese problems of the Olympic Peninsula, Washington. Am. Jour. Sci. 244, 305-323, 1946.

- On the origin of manganese, Internat. Geol. Cong., 20th, Mexico 1956.

PzAcock, M. A., The palagonite formation of Iceland, Geol. Mag. 63, 385-399, 1926a.

- The geology of Videy, southwest Iceland; a record of igneous action in Glacial times, R. Soc. Edinburgh, Tr., 5A, 441-465, $1926 \mathrm{~b}$.

- The Petrology of Iceland, (TYRRELL and PzAOOCK) Part 1, The Basic Tuffs. R. Soc. Edinburgh, Tr., 55, 51-76, $1926 \mathrm{c}$.

- and R. E. FULLR, Chlorophaeite, sideromelane and palagonite from the Columbia River plateau, Am. Mineralogist, 13, 360-382 1928.

PETTERSSON, H., Iron and manganese on the ocean floor; a contribution to submarine geology, Goteborgs Kungl. Vet. o. Vitterh. Samh. Handl; 6. foljden, ser. B, band 2 , no. $8,1-43,1945$. 
Pettresson, H., Manganese nodules and oceanic radium, Deep-Sea Research, 3 Supp., 335345, 1955.

- Manganese and nickel on the ocean floor, Geochim. et Cosmochim. Acta 17, 209-213, 1959.

RiEDEL, W. R., LADD, H. S., TRACEY, J. I. Jr., and M. N. Bramlette, Preliminary drilling phase of Mohole Project, ii. Summary of coring operations (Guadalupe Site), Am. Assoc. Petroleum Geologists Bull., v. 45, 1793-1798, 1961.

Ritrmann, A., Volcanoes and their activity, Translated by E. A. Vincent, Interscience Publishers, John Wiley and Sons, New York, 305, 1961.

Rosenbusch, H., Mikroskopische Physiographie der Mássigen Gesteine: II, Ergussgesteine, Stuttgart, 717-1592, 1908.

SNAVely, Parke D., Jr. and H. C. Wagner, Tertiary Geologic History of Western Oregon and Washington, Am. Assoc. Petroleum Geologists Bull., v. 46, no. 2, 280, 1962.

TALIAFERRO, N. L., and F. S. HUDSON, Genesis of manganese deposits of the coast ranges of California, California Div. Mines Bull., 125, 217-275, 1943.

Von Waltershausen, W. SARTORIUS, Physisch geographische Skizzen von Istand, Gottingen, 1847.

WATERS, A. C., Geol Soc. America, spec. paper, 62, 703-722, 1955.

, Determining direction of flow in basalts, Am. Jour. Sci., v. 258A, 350-366, 1960.

\section{Discussion}

R. L. HAY: 1) Is the palagonite you described amorphous to X-rays? 2) Have you observed the alteration products of rhyolitic glasses in marine sediments?

R. Y. NAYUDU: 1) It is mostly amorphous it appears. Recent X-ray studies of fresh palagonite suggest the only crystalline content is nontronite or goethite and in some cases smectite. 2) I studied andesitic glass of at least 25,000 years old in the Gulf of Alaska. It does not show alteration only except for little zeolitization. 